\title{
Church and war: A change in hermeneutical stance among Pentecostals
}

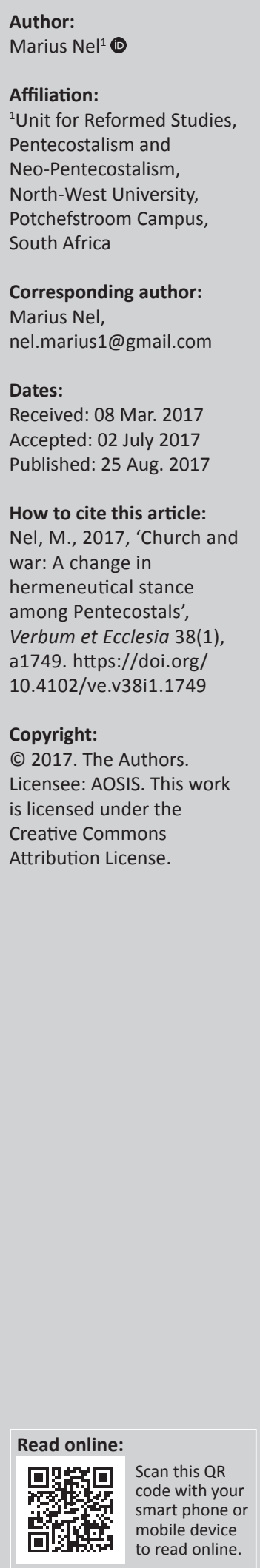

At its inception and for the first 40 years of its existence, Pentecostalism was a pacifist movement preaching non-violence and non-retaliation. At the end of the Second World War, the movement changed its stance, in many instances without officially taking a decision at formal platforms, because of the changes that occurred when its members became socially and economically mobile and the movement strove to be accepted in society. The article argues that the changes were, however, essentially because of a change in its hermeneutical viewpoint that introduced a new climate within the movement, accompanied by various changes in viewpoint and practice. After the 1970s, several theologians within the Pentecostal movement formulated a hermeneutics that concurred to a large degree with the way early Pentecostals viewed and interpreted the Bible. This new hermeneutics allows Pentecostals to rethink their non-pacifist stance and the article argues the case for such a reconsideration.

Intradisciplinary and/or interdisciplinary implications: While the classical Pentecostal movement supported pacifism for the first 30 years of its existence, it changed its stance at the end of the Second World War because of new hermeneutical choices. Recent changes in hermeneutical viewpoint within (a part of) the movement require that the ethical issue of pacifism be rethought if it does not want its witness about Jesus Christ as the source of peace to be compromised.

\section{Introduction}

\section{A case study}

The early Apostolic Faith Mission of South Africa (AFM), one of the classical Pentecostal denominations in southern Africa, did not at first find it necessary to take a stand about Christians' participation in the armed forces and war. ${ }^{1}$ Everybody implicitly accepted that Pentecostal Christians do not participate in any violence, including war operations. ${ }^{2}$ However, in 1914 the then president of the church, Pieter Louis le Roux, took the initiative and requested the Executive Council to discuss the issue and formulate a viewpoint. Their decision was communicated in a letter to individual churches and members and explained that the AFM objected to Christians' participation in war efforts against the enemies of the state. Members of the AFM who were called up for military service were encouraged to serve in a non-fighting capacity if it became absolutely necessary (Burger 1987:269). At the same meeting, the Executive Council decided to make representations to the Minister of Defence requesting exemption from military service for members of the AFM (Minutes of the Executive Council, 19 August 1914). The Department was sympathetic towards the church's request, allowing members with scruples to receive exemption from military service provided they applied in the prescribed way.

In 1923 the Executive Council again discussed the issue of warfare and made representations to the Department of Defence that while their acceptance of Scripture does not permit them to take up arms they ask that the clause in the previous Defence Act that exempts conscientious objectors from carrying arms be included in the present new Law that was in the process of being considered by Parliament. The church acknowledged its obligations to assist in bearing the burdens in times of war and does not object to do so, but then in a non-combatant capacity, requiring also exemption for the church's young members to undergo military training (Minutes of the Executive Council, 21 December 1923; cf. Burger 1987:270). The Department reacted by providing the church with the declaration that assures that exemption would be granted to members, although they were required to register at the Department, and that the new Law would contain the exemption clause.

\footnotetext{
The article is written from the perspective of a white member of the AFM of SA. Early on, the AFM divided along racial and language lines and the black AFM's consideration of pacifism differs in many respects from the white AFM before 1996. The theological lines and the black AFM's consideration of pacifism differs in many respects from the white AFM before 1996 . The theological
convictions and resultant ethical considerations of the mostly black AFM assemblies need to be recorded; no research has been convictions and resultant ethical
published from that perspective.
}

2.For the reason that with the application of violence nobody wins except to lose everything in despair (Rutgers 1933:133). 
By 1932, the Department of Defence had received so many applications for exemption that it decreed that members of churches applying would be required to present proof if they were previously members of another denomination that did not support exemption (Burger 1987:270).

By 1938, it was clear that a world war was imminent and the (white) AFM again discussed its stance. The AFM agreed in its viewpoint with the Assemblies of God in the USA that although believers should act in accordance with their own conscience, the AFM was of the opinion that the Bible prohibits the shedding of blood while at the same time it recognised that the government is of divine origins, giving its assurance that it would support the government as far as the Word of God allows it (Dempster 2001:140). When war broke out in 1939, young members were encouraged to participate in the war effort but only in a non-combatant capacity by applying for non-fighting privileges (Burger 1987:271).

Since the Second World War, the AFM never officially changed its stance on believers' participation in warfare, but practice shows that the white division of the AFM did change its viewpoint, as a result of the rise of Afrikaner nationalism and a new interest and involvement in politics from the side of some church leaders. Today the church has several chaplains serving the different departments of the defence ministry (Burger 1987:272-273). For the Pentecostal movement it became essential after the Second World War to be accepted by society and government, leading inter alia to an alliance with Evangelicals. In accordance with Reformed theology, Pentecostals accepted the Christians' responsibility to partake in actions that serve the welfare of the state, including war, while they also created a professional pastorate in place of the democracy of members participating in early Pentecostal ministry and worship services, and they cut out women from the official ministry of the church (Archer 2009:23-24; Cargal 1993:165-166).

The AFM is part of the Pentecostal movement and followed in its wake. Before discussing some of the reasons for the change in viewpoint about warfare it may be beneficial to briefly discuss the Christian church's different views of war through the centuries.

\section{Different theological views of war and violence}

The Christian response to war should begin with a consideration of what the Bible teaches on the subject. ${ }^{3}$ The teaching of aggressive war in the Hebrew Bible has served as justification for many Christians to engage in armed conflict

3.Technically, war is hostility and violence for the sake of asserting oneself (Rutgers 1933:123). It can also be defined as 'legitimized murder on a mass scale' (Hauerwas 2001:394). 'War' should be defined in broad terms, as a particular war between nations where 'enemies' attack one another, that implies the arrogance that a given nation (represented by a clique of political rulers who claim to bear the interest of the nation at heart) presumes to impose its vision of the future on the rest of the world claiming some more right or duty by virtue of its power rest of the world, claiming some more right or duty by virtue of its power, success or philosophy, and which is idolatry in that it makes of one's own nation's welfare an ultimate value to which if necessary that all else must be sacrificed (Yoder 1971b:55-56). War can also originate from ethnic disagreements. But 'war' can also refer to the positive rejection of a racist, exploitative, dehumanising 'system', the unequal and unjust distribution of wealth, the distribution of drugs among exploited peoples or of systematised world injustice (Sölle 1983:125).
(Hershberger 1953:20-22). The New Testament broadened the believer's understanding of the kingdom of God, but does not contain specific instructions about the subject of war (Clouse 1981:11) although it states explicitly that human vengeance belongs to sinful society and Christians are forbidden to exercise it (Hershberger 1953:22). ${ }^{4}$ The early church in the first three centuries took a pacifist view towards violence (Bakhuizen van den Brink 1933:49), followed later by the humanists and Anabaptists. Early Christians refused to serve in the Roman army; there is no evidence of a single Christian soldier after New Testament times until about 170 CE (Clouse 1981:12). Roman soldiers who converted immediately cast their weapons to the ground, turning soldiers into pacifists (Dempster 1991:65). Roman soldiers were denied Holy Communion if they engaged in the immoral practice of killing other human beings (Bartleman 1915:83). Tertullian argues that Christians cannot take the life of a person God purposes to redeem (Augsburger 1981:92). The Romans did not enforce universal conscription and there was little need to discuss the issue in the church; Christians saw an incompatibility between love and killing. Towards the end of the second century there are records of Christians in the army despite theologians' condemnation of participation in war. Origen discusses the problem of Christians who participate in warfare rather than spiritual conflict, quotes Matthew 26:52 and concludes that taking up the sword is not allowed for believers by evangelical teaching (Clouse 1981:12).

Half a century later, the Roman Empire was threatened with annihilation by destructive groups such as the Vandals. A Roman general who commanded troops in North Africa asked Augustine whether he should retire to a monastery or lead his troops in warfare against the barbarians (Holmes 1981:128). Most Christian groups agree with Augustine's answer that certain wars were justified, and at times even necessary (Kwast 1995:30). ${ }^{5}$ A just war consists of rules of warfare developed by classical thinkers such as Plato and Cicero, interpreted from a Christian perspective. War should be fought to restore peace and to obtain justice, under the direction of the legitimate ruler and motivated by Christian love. Some churches such as the Church of the Brethren, the Quakers and Mennonites maintain a pacifist stance (Bakhuizen van den Brink 1933:76-77), but most of the major denominations, such as the Lutherans, Presbyterians,

4. Hauerwas' (1985.113) remark is relevant that Jesus is the meaning and content of the kingdom. That the kingdom is present in Jesus is known not only by Jesus' power to renew our spirit and nature, but also in the rehabilitation of his people. Among God's people, the poor, the oppressed and the underprivileged play a particular God's people, the poor, the oppressed and the underprivileged play a particular
prominent role, as their reversal of fortunes proclaim that all is not well with the prominent role, as their reversal of fortunes proclaim that all is not well with the
world. Their unencumbered reception of God's forgiveness and grace sets them apart as God's people, and they have learnt to forgive and show grace, even to their enemies. The kingdom consists of a peaceful space (Hauerwas 1985:115-116).

5.The church has to accept that it is part of an imperfect world, as expressed by Augustine's catch phrase, semper tolerans terram, sperans coelom (carrying or enduring the world while awaiting heaven) (Bakhuizen van den Brink 1933:83). At the same time, Augustine emphasises the 'not yet' dimension of the kingdom; he views war as both the result of $\sin$ and a tragic remedy for sin and the life of political societies in the sense that it restrains evil and protects the innocent (Hauerwas 2001:411). It implies that as long as Christians live in history there must exist an $2001: 411)$. It implies that as long as Christians live in history there must exist an
unresolved tension between justice and nonviolence. This tension requires the Christian to use violence in the cause of justice, as law enforcers experience in the
execution of their tasks. However, in practice wars are seldom fought to protect the people but rather for the advancement of political leaders' ambitions cancelling the people but rather for the advancement of political leaders' ambitions cancelling
the logic of the just war theory from the analogy of self-defence of the innocent the logic of the just wa
(Hauerwas 2001:412). 
Baptists, Roman Catholics, Methodists and Reformed adhere to the just war interpretation (Kwast 1995:35-52). ${ }^{6}$

Constantine the Great was proclaimed emperor in $307 \mathrm{CE}$, converted in $311 \mathrm{CE}$ to the Christian faith and made Christianity the official religion of the Roman Empire in 313 CE. This is a turning point for Christians (Nuttail 1958:4). Before Constantine, they were liable to persecution at any time, but since $313 \mathrm{CE}$ Christians had not been liable to persecution as the official policy throughout the civilised world for many centuries. The changed circumstances influenced the spirituality of the church and led to the gradual and steady growth of moral laxity. ${ }^{7}$ The church lost the battle to redeem the world, and rather conformed to it, losing the power of the Spirit to overcome evil in the world with good (Nuttail 1958:5). ${ }^{8}$

The situation in Europe changed because of the break-up of the Empire and the influx of Germanic tribes from the fifth century. A new militant attitude was formed in the church in accordance with political needs. The Germans' greatest virtues centred on devotion to gods of battle and the desire to die in conflict and eventually a fusion of the Germanic religion of war and the religion of peace among the Christians of Western Europe took place, leading to the conviction of the absolute evil of the enemy and the necessity of a Christian crusade, for instance, towards the Turks from the eleventh to the 15 th centuries.

Christians react towards war in four ways, as Christian pacifism ${ }^{9}$ or non-resistance, the just war and the crusade (Sölle 1983:29). The stance of non-resistance towards war is deduced from Matthew 5:39; Luke 6:27-36; Romans 12:1921; $13: 8$ and 1 Peter 2:18-24. Hoyt (1981:32-34) bases the stance on the Christian's separation from the world in Paul's advice not to be conformed ( $\mathrm{Rm} 12: 2)$, resulting in a separation between church and state belonging to separate kingdoms and spheres of operation, with different methods of offense and defence. ${ }^{10}$ The implication is that physical violence is forbidden to believers as a method to accomplish any purpose (1 Pt 2:21-24), not even to propagate the Christian faith (2 Cor 10:4). The doctrine of non-resistance rests upon certain principles that the kingdom of Christ is

6.See Thyen's (1972:104-105) discussion of the important relation between ecclesiology and morality, and pacifism in particular. The church lives from eternal principles that accompany its call and that should determine its independent character and relation to life in general and the authorities in particular (Severijn 1933:86).

7.Eventually this led to what Kwast (1995:9) calls the 'dieptepunt' of the Thirty Years War (1618-1648), at the same time a civil and international conflict involving
Austria, the Netherlands, France, Denmark and Sweden, costing the lives of more Austria, the Netherlands, France, Denmark and Sweden, costing the lives of more
than a third of the population and ruining Central Europe politically and socially. The tragedy was that the Christian church was the initiator of the war.

8.For this reason, Heering (1952:5) writes about the 'nachkonstantinische Kriegstheologie', growing from the panic to render unto Caesar what is Caesar's while ignoring the necessity of a healthy distance between church and state in order to protect the church's prophetic task towards the state.

9.There is not a single position called 'pacifism' held by all pacifists and to which a clear definition can be given. There is rather a congeries of varied kinds of opposition to war; while some of them run parallel others are very different from one another in accent and sometimes even in substance. By labelling them together one does violence to the one or the other (Yoder 1971b:10).

10.Cf. the remark of a Mennonite (quoted in Yoder 1971a:98) that his family has never taken part in war 'because we have nothing to do with the world and its ways. I has nothing to do with us what the world does'. not of this world, and therefore that the subjects of this kingdom should not employ force to maintain it (Jn 18:36); the Spirit of Christ is not of this world and therefore those who possess the Spirit cannot use carnal methods (Gl 5:22; Mt 5:9); the purpose of Christ is not of this world for he came to save and not to destroy (Lk 9:56); and his methods are not of this world and he does not use carnal weapons in his warfare (2 Cor 10:3-4) (Hoyt 1981:42-44). ${ }^{11}$ The implication is that Christians may participate in war only as non-combatants.

While non-violence is a vocational calling for the church and not for society as such, and while the total world stands under the moral demands of a sovereign God, it is also true that living in society requires one to operate 'outside the perfection of Christ' (Augsburger 1981:58-59). This requires of Christians that they have nothing whatsoever to do with war (Mi 4:3; Lk 6:27-36; Jn 18:36). Their highest loyalty should be to the kingdom of God, and because that kingdom is global, a Christian in one nation cannot honourably participate in war which would mean taking the life of (among others) a Christian in another nation. Their separation from the world is not simply a negative separation, but a positive separation to the community of Christ and to building the kingdom by evangelising efforts (Augsburger 1981:61). They are not simply to refrain from participating in war but should risk their lives for the extension of the kingdom. Martin Luther King's (1958:81-83) pacifism consisted of nonviolent resistance that asks one to stand for love rather than to strike back. Its resistance does not seek to defeat or humiliate the opponent but to win friendship and understanding because the attack is directed against forces of evil rather than against the people doing evil. The resistance avoids not only external physical force but also internal violence of spirit. Christians should be excellent citizens, respect the government and pray for those in authority but their citizenship in a given nation is second to their primary citizenship in the kingdom of Christ. For this reason they are pacifists, refusing to support any military enterprise, even non-combatant service that still supports the function of war and at best only releases the individual from the responsibility of directly taking a life.

In contrast, the just war theory does not allow retaliation nor does it sanction every war and every military action but allows believers and Christian governments to participate in limited defensive wars (Holmes 1981:65). ${ }^{12}$ It accepts that war and its causes are evil. The issue is not whether war is good but whether it is in all cases entirely

11.In its Barmen Declaration of 1934, the Confessing church under the leadership of Karl Barth, Martin Niemöller and Dietrich Bonhoeffer declared a status confessionis, implying that one cannot be a Christian and at the same time support the Third Reich of Hitler. The same can be said of the support of nuclear weapons (Zink 1983:89).

12.See Johnson (1975:150-254) for a discussion of the development of the philosophical principles of a secularised just war doctrine, in contrast to the holy war rationale. The peace movement, it is argued, threatens the peace because peace can only be guaranteed by strength (Hauerwas 2001:393). Violence is that to which individuals, whether they be particular persons or foreign states, resort in which individuals, whether they be particular persons or foreign states, resort in
order to challenge the legitimacy of power. When power breaks down, violence is often the result (Hauerwas 2001:404). 
avoidable (Holmes 1981:117). ${ }^{13}$ The church should resist evil but not by violent means. It should rather do so by preaching and teaching, by ministering to the needs of those who might be tempted to erupt violently against society, by supporting just and compassionate government and by protesting social evils and injustices. However, proponents argue that Matthew 5:39 (and related texts) supporting nonviolence refers not to governments or churches but to individual Christians (Holmes 1981:116). Individuals are not to take the law into their own hands, but instead of carrying out retributive justice (lex talionis), they should turn the other cheek and go the second mile. The implication is not that justice does not matter but that the individual believer does not have a stake and no part in law enforcement. Non-resistance calls for love to replace hatred and for just and limited punishment to replace kangaroo courts, blood feuds or lynch mobs. The government is God's means of justice, and retributive justice may at times require of the government to participate or even initiate in a just war. This does not imply that war is justified, but rather that it tries to bring war under the control of justice so that, if consistently practised by all parties to a dispute, it would eliminate war altogether (Holmes 1981:119-120).

If Christians and the church are parts of a larger community, as citizens it may be expected of them to assume responsibility for and participate in the business of the state. Reformed theologians accept the 'political use of the Law', that is, the doctrine that scriptural principles should guide not only the church, but also the secular state and civil society (1 Tm 1:810) (Brown 1981:174-175). Waging war can be justified in the case of a defensive war against an unprovoked act of aggression, the only just cause for going to war, provided that the defence has some chance of succeeding and the means chosen are proportionate to the end to be achieved. ${ }^{14}$ Most of the actual war situations that arise in history do not fit this category (Brown 1981:153), while the atrocious and enduring nature of the oppression caused by some dictatorships and tyrannical enemies requires that they be stopped forcefully. A preventive war or crusade is begun not in response to an act of aggression, but in anticipation of it. This is not a holy war because it is not religiously motivated but serves as an attempt to prevent an anticipated act of oppression (Brown 1981:162); Sölle (1983:29) correctly calls it un-Christian and unacceptable.

\section{Pentecostals and pacifism}

Early Pentecostals viewed its origins in restorationist terms where they read the New Testament in the service of conceptualising the presence of God in the faith community, resulting in a return to the ecclesial forms and practices of the

13.Schoonhoven (1935:83), writing in the run-up to the world war, generalises that the true cause of all wars is in an economic competition ('concurrentiestrijd') between nations caused by the population explosion and the needs of different nations. The economic conflict gives rise to political and military blocs of power, creating tension between different blocs; war is the discharge of the tension. For this reason he argues that no war can be justified as just.

14.The application of justice to war requires a just cause, a just intention, war as a last resort, a formal declaration by the highest authorities, limited objectives, proportionate means and non-combatant immunity (cf. discussion in Holmes 1981:120-121). early church, as described in the book of Acts (Shuman 1996:72). Yoder (1983:307) acknowledges that Pentecostals perpetuated the restorationist communities of the 19th century that were pacifist because of its literal obedience to Scripture, especially Jesus' command and example of love for the enemies and turning the other cheek. Early Pentecostals did not partake in politics for several reasons: because of their socio-economic position, mainly as part of the lower classes who do not have money, training or leisure to be social leaders; because of their expectation that the second coming is so imminent that time should rather be used to preach the gospel to the lost; and because of their notion of sanctification that defines holiness in terms of separation from the world, consisting of differentiating itself from its social, cultural and political environment with a view to live a holy life (Nel 2016:158). In the end, however, it was their way of interpreting the Bible, their hermeneutics that led nascent Pentecostals to maintain that it was wrong for one human being to kill another (Yoder 1971a:41). And even when the Bible presents contradictory information about violence, war and vengeance they interpreted Scripture in close association with the Spirit who revealed the love of Christ for them and all people, motivating them to evangelise the lost with the gospel of love. ${ }^{15}$ The emphasis is on the principles found in the Sermon on the Mount (Mt 5-7), characteristics like love, forgiveness, reconciliation and tolerance determining the behaviour of Jesus' disciples and the promise of a new earth and heaven where justice will rule while the church is a reflection of that kingdom (Kwast 1995:57-58).

Blumhofer (1989a:18) argues that their hermeneutics determined Pentecostals' view of themselves as a church awaiting the imminent second coming of Christ, fleeing from denominational Christianity that became irreparably contaminated when in the fourth-century church and state joined forces to establish an earthly kingdom that could never accommodate the reign of God envisioned by Jesus. ${ }^{16}$ By joining Pentecostalism, early participants had separated from the mainstream and when they faced discrimination and persecution from the establishment and its churches they interpreted it eschatologically as a sign of their faithfulness and readiness for the eschaton (Blumhofer 1989a:19). They were now persecuted as the early church was persecuted by

15.Shuman (1996:79) suggests that the evolution of ethics among early Pentecostals showed little attachment to specific theological convictions. They were informed by the gospel message, but it did not inform their ethical stance. They simply 'know' right from wrong as a function of their being human. I do not agree and 'know' right from wrong as a function of their being human. I do not agree and
rather suggest that their ethical thinking was informed by their sanctified rather suggest that their ethical thinking was informed by their sanctified
conscience, as a result of the quickening of their conscience by the Spirit in their conscience, as a result
reflection on Scriptures.

16.Absolute pacifists among early Pentecostals used several arguments to justify their pacifism: believers have the moral requirement to separate from the dominant values and practices of human culture and express the moral value that God places on all human beings; in the light of its restorationist understanding of the history of the church militarism is seen to have entered the church's life when the church backslid and forged a political alliance with the Roman state; pacifism was the normative position on military service within the early church; Christians were heavenly citizens and pilgrims on earth with no allegiance to civil authorities; and to live completely separated unto God a position of separation from nationalism is required (cf. Dempster's 2001:141-146 discussion of popular theological tracts of required (cf. Dempster's 2001:141-146 discussion of popular theological tracts of the early period). Dempster (2001:162) adds that Pentecostal pacifism restores vibrant apostolic faith, resists assimilation into an exploitative, war-ridden world affirms the value of human life, critiques the existing sinful social order and affirms the universal value of humanity. The different theological convictions and ethica principles used to justify Christian pacifism lead Dempster (2001:163) to typify a sectarian, dispensationalist, prophetic and ethical-humanitarian pacifism among early Pentecostals. 
the Jewish religious establishment and Roman state because they were citizens of the kingdom of God with allegiance only to God, pilgrims and strangers in this world (Heb 11:13) who refused allegiance to earthly authorities. To participate in war was regarded as incompatible with their citizenry of the kingdom not only because violence inherent in war was wrong but also because allegiance to God requires one to love the enemy (Zink 1983:62). Christians should busy themselves with spiritual warfare (2 Cor 10:3-5) in a struggle infinitely more important than any political war between nations (or, more correctly, nation-states). Nationalism was a sin, and pride in race and nation was an abomination (Blumhofer 1989a:351). ${ }^{17}$

The Pentecostal worldview shared some apocalyptic elements with the Church of Acts that views Jesus not only as risen Saviour but also as ascended Lord of the universe, and earthly powers to be under the control of Christ (Yoder 1984:72). The state acts as an agency of the world whose purposes will always be at odds with those of the kingdom of God. Earthly wars form part of a cosmic dispensational drama that involved the judgements of God on earth, leading to the rapture and uniting of the church with Christ and the destruction of the Antichrist when Christ returns to reign for a thousand years on Mount Zion (in the words of Mary Boddy in Lenz 2008:293).

Pentecostals ascribed the decline of the early church from its Jewish roots to its accommodation when it encountered the Hellenism of Asia Minor and southern Europa as well as political privilege when Constantine was supposedly converted, leading to the eventual establishment of Christianity (sometimes called 'Christendom' to differentiate it from earlier Christianity) as the state religion and the church's implicit acceptance of state violence, eventually was also utilised against the church's 'enemies' (Yoder 1984:82). In order for the church to occupy a position of relative power it had to affirm the civil authorities; the price it had to pay was its abandonment of the particular ethical convictions that defined the Christian faith. Yoder (1984:136-137) states that it led to a theological shift towards a new ecclesiology and eschatology as well as a changed view of history and the way changes within history were regarded, adopting the state's eulogistic view of history, and a morality defined by the ruler's ability to meet its standards.

\section{Pentecostals and non-pacifism}

While the Pentecostal movement started out as officially pacifist, certain events and developments in the 1940s and 1950s triggered a basic shift in Pentecostal belief about Christians bearing arms and partaking in battles (Dempster 2001:140). In a certain sense Pentecostals repeated history; in its quest to shed its image as a sect and the accompanying discrimination at the hand of established denominations, Pentecostals like the church in the fourth century started seeking for acceptance and approval by the state and community. Predominantly this happened because of Pentecostals' assimilation into the cultural and religious mainstream during and following the Second World War (Beaman 1989:140). Pentecostals from the 1940s experienced social and economic mobility, requiring them to gain acceptance as a denomination and cultural accommodation and for this reason they became part of the National Association of Evangelicals in 1942 (Robeck 1988:635). Without much discussion, pacifism was left out of the agenda and in some cases this was worded to give members the freedom to act according to their conscience and choose for themselves whether to be a combatant, a non-combatant or a conscientious objector (Statement accepted at the General Council of the Assemblies of God in 1967, quoted in Dempster 2001:137).

The nature of its growth also contributed to the blunting of its radical vision of the kingdom of God as the establishment of a peaceful community of the church when many new converts joined the movement while their views were still conditioned by the ethic of a nominal Christian culture, leading to a spiritual downturn among Pentecostals (Burger 1987:311). In South Africa the Nationalist Party was elected into government in 1948, handing political power into the hands of Afrikaans-speaking people and leading to a new patriotism in their ranks (Giliomee 2004:438). In the AFM, Pastor G.R. Wessels, vice president of the church, was elected as a senator for the Nationalist Party after acquiring fame for speaking about the dangers of communism. Some members and pastors saw this move as incompatible with the AFM's vision of the church and kingdom of God, and left the AFM to establish the Pentecostal Protestant Church in 1958 (Burger 1987:324, 345).

At the same time, Pentecostals took significant steps towards an establishmentarian ecclesiology (Shuman 1996:85) with a professional pastorate that reflected the practices of Evangelicals. And its view of the state now also conformed to Evangelicals' view, with liberal democracy as an underlying assumption undergirding both Christianity and the present authorities. This principle is even more important and significant than the Gospel, which is but a historical manifestation of the principle, so that military action can be justified by the church if needed to preserve the principle of democracy (Blumhofer 1989b:212; Hauerwas 1985:122-130). Ethics also changed accordingly because now the church must aim its behaviour to strengthen the regime (Yoder 1984:136). The established powers of civil government and not the average believer praying and partaking in the establishment of the kingdom of God were seen as the main bearers of the historical movement (Yoder 1984:138).

\section{Restoring pacifism among Pentecostals: A moral alternative}

Post-1994 South Africa saw the powerful lose their grip on political power (however, to a large extent not on economic power), and the AFM unified in 1996 and reaffirmed its 
loyalty to the government (Burger \& Nel 2008:439). The 1997 Workers' Council of the AFM decided to unconditionally accept responsibility for the fact that the (white division) church was not the voice of God of reconciliation in the country for the period when the community was separated by racism (Burger \& Nel 2008:439). History now repeated itself when Frank Chikane, elected as vice president of the unified AFM in 1996, was appointed as the Director-General in 1999 in the office of the presidency under Thabo Mbeki. ${ }^{18}$ During the years of the democratic South Africa the AFM has been issuing statements, articles and press releases about several political and economic issues that challenged the government and other organisations to change several legal and practical issues, demonstrating its involvement as a church in political issues. ${ }^{19}$

Since the 1970s a debate has been recurring in Pentecostal circles about the early hermeneutics of the Pentecostal movement and its relevance for interpreting the Bible. If this debate is considered seriously the movement should consider placing pacifism on its agenda, as it has done with the issue of women in the ministry. If Pentecostals are interested in reading the Bible in the light of their restorationist heritage it will consider its position as the contemporary manifestation of the 'last days' community founded on the book of Acts (Shuman 1996:90). Even though Pentecostalism has been institutionalised, its privileging of Acts should remain a contemporary characteristic in order to preserve its essence and identity.

Hauerwas (1988:48-49) notes that war originated when human beings at Babel believed that they were capable of living without the acknowledgement of their creatureliness, and hence without God, leading to the fear of the other becoming the overriding passion which motivated each group to force others into their story or to face annihilation. Pentecost, however, restored what was destroyed at Babel, which consisted in the scattering of humanity by the confusion of different languages (Gn 11:5-9). Jesus bore witness of a new possibility of relationships based on peace and love; he characterised it as the reign of God, a community consisting of the restructuring of relationships achieved by the intervention of the same Spirit who anointed the Christ ('anointed one') (Yoder 1994:39). For this reason, Christians believe that God, through Jesus Christ, has inaugurated a history that frees all people from the assumption that there is no moral alternative to war (Hauerwas 2001:397). The reign of God represents a social ethic; the story of Jesus is its social ethic (Hauerwas 1981:40). Spirit baptism engendered glossolalia as a sign that in Pentecost God had begun to gather together the world's scattered peoples into one new people (Hauerwas 1988:50). Babel's divisions and their resultant hostilities have been overcome. The church as an actual way of living among a concrete group of people has

\footnotetext{
18.Chikane was elected as a member of the African National Congress' Nationa Executive Committee in 1997. He was also consulting for Presidents Kgalema President of thellowship between AFM National Churches in all countries.
}

19.Cf. AFM of SA (n.d.) for some of these statements. become an alternative to Babel, the way this world operates. In telling their story the church becomes the story, of peace, love and justice (Hauerwas 1988:54). Where the absence of any authority above states to prevent or adjust conflicts leads to the inevitability of war, the restoration of the kingdom of God on earth in the shape of the church establishes God as the highest authority (Hauerwas 2001:407), making peace a possibility amid a world at war. The kingdom is not only yet to come but has also been made present fully in Jesus Christ and through the baptism in the Spirit in the church. ${ }^{20}$ The miracle we call the church is God's sign that war is not part of his providential care of the world (Hauerwas 2001:424).

The eschatological aspect of Spirit baptism should be appreciated as an empowerment that changes the community into a radical witness to the story of Jesus. An important aspect of its radical nature is Pentecostalism's social ethic that serves as the basis for pacifism. Instead of further deepening and strengthening its alliance with the government (or opposition parties), Pentecostals should rely on the principles and ideals of the biblical accounts of Jesus and the early church. This would inter alia require that Christians share in God's kenosis; though Jesus was God, he did not cling to his equality with God but gave up his divine privileges and took the humble position of a slave in order to be born as a human

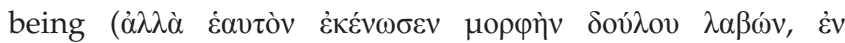
ó to non-violence is therefore not primarily an ethic but a declaration of the reality of the new age, where a direct relationship exists between the way Christ suffered on the cross and the way his disciples are called to suffer in the face of evil (Mt 10:38; Mk 8:34-38; 10:38-45; Lk 14:27) (Yoder 1971b:60).

Pentecostals should become the embodiment of the new humanity whose Spirit-filled lives make present to the world the reality of God's kingdom (Shuman 1996:96). In the kingdom no-one participates in killing as a means of vengeance; they live in peace with one another as far as possible (Heb 12:14) because the peace of the Christ rules in their hearts (Col 3:15). Violence and war is fundamentally immoral (Hauerwas 2001:410). Especially in the atomic age where a war may claim the lives of millions of people and even destroy the earth (Kwast 1995:94), the pacifist voice needs to be heard urgently.

Pentecostals should base their ethics of pacifism on Scripture. Current times see difficulty in appreciating the moral role of the Bible because in Hauerwas's (1981:53) words, we have forgotten that the authority of the Bible is a political claim characteristic of a very particular kind of polity. This does not imply that the authority of the Bible should be used as an ideology for

20.The notion that the early Christians were pacifists only because they had a mistaken apocalyptic idea that the world was soon to end and that direct political involvement would be fruitless and that when the end failed to arrive Christians involvement would be fruitless and that when the end failed to arrive Christian reluctantly took up the means of violence in the interest of justice is mistaken. The early Christians did look for God's reign immediately to become a reality for a people but that did not disqualify their dedication to live in that reign here an now (Hauerwas 2001:419). In the church era the two ages overlap and exist simultaneously, although they differ in nature and direction with one pointing backwards to human history outside of Christ and the other pointing forward to the fullness of the kingdom, of which the church is a foretaste (Yoder 1971a:58). 
justifying the demands of the oppressed, but rather that it derives its intelligibility from the existence of a community that knows its life depends on faithful remembering of God's care for his creation through the calling of Israel and the life of Jesus. Failure to appreciate how the biblical narratives have and continue to form a polity is part of the reason that the ethical significance of the Bible currently seems so problematic (Hauerwas 1981:54-55). To claim the Bible as authority is the testimony of the church that this book provides the resources necessary for the church to be a community sufficiently truthful so that our conversation with one another and God can continue across generations. Scripture forms a community and sets an agenda for its life that requires the church to trust its existence to God found through the stories of Israel and Jesus, and the moral use of the Bible lies in its power to remember these stories for the continual guidance of the community (Hauerwas 1981:66). ${ }^{21}$ Being a community of the forgiven allows it to become an agent of forgiveness and grace, disqualifying its members to partake in any form of violence or war. Only in this way does the church become worthy to continue carrying the story of God that it finds authorised by Scripture with an enthusiasm that cannot be defeated because it knows that as a community of peace it nurtures habits of peace that might be able to see new opportunities not otherwise present because it represents a kind of people who have been freed from the assumption that war is our fate (Hauerwas 2001:424).

\section{Conclusion}

Pentecostalism changed after 30 years of existence from a nonpacifist movement to a collaborator in the nations' wars. It is argued that this happened as the result of a change in the hermeneutical stance when during the 1940s Pentecostals and Evangelicals took hands to co-operate, and Pentecostals accepted Evangelicals' viewpoint of patriotism and nationalism. However, since the 1970s Pentecostals reformulated their hermeneutics in terms of the practice of the movement at the time of its inception, leading to several important changes in its doctrine and practice. What is now needed is that the movement also visits its stance towards pacifism. Future research should explain the implications of such pacifism for Pentecostals. A new hermeneutics should lead Pentecostals to rethink their non-pacifist stance in favour of the ethical decision to support peace as defined by their witness about Jesus Christ as the source of peace.

\section{Acknowledgements Competing interests}

The author declares that he has no financial or personal relationships that may have inappropriately influenced him in writing this article.

21. Christians believe that the true history of the world is not carried by the nationstate; the history of the world is one of godlessness. The church knows what war is; the world is too broken to know what lies behind wars. For war is the desire to get rid of rid of God, to claim for themselves the power to determine the meaning and destiny of humankind (Hauerwas 2001:421). Humanity demonstrates its hatred of God by the way it eliminates the enemies in the name of protecting the common history they share. Christians share the possibility of a different history through their participation in a community in which one learns to love, even their enemies. The world's true history is not that built on war but that offered by a community that witnesses to God's refusal to give up his creation.

\section{References}

AFM of SA Executive Council, Minutes of the Executive Council, 19 August 1914, AFM Archives, Johannesburg.

AFM of SA Executive Council, Minutes of the Executive Council, 21 December 1923, AFM Archives, Johannesburg.

AFM of SA, n.d., Media, viewed 09 February 2017, from http://www.afm-ags.org/ media

Archer, K.J., 2009, A Pentecostal hermeneutic: Spirit, Scripture and community, CPT, Cleveland, $\mathrm{OH}$.

Augsburger, M.S., 1981, 'Christian pacifism', in R.G. Clouse (ed.), War: Four Christian views, pp. 58-114, InterVarsity, Downers Grove, IL.

Bakhuizen van den Brink, J.N., 1933, 'De oorlog in de geschiedenis der Christelijke kerk', in H.T. Obbink et al (eds.), Kerk en oorlog: Vijf voordrachten, pp. 48-84, Erven J. Bijleveld, Utrecht.

Bartleman, F., 1915, 'War and the Christian', Word and Work, 2, 83.

Beaman, J., 1989, Pentecostal pacifism: The origins, development and rejection of pacifist beliefs among the Pentecostals, Center for Mennonite Brethren Studies, Hillsboro.

Blumhofer, E., 1989a, The Assemblies of God: A chapter in the story of American Pentecostalism, vol. 1: To 1941, Gospel Publishing, Springfield.

Blumhofer, E., 1989b, The Assemblies of God: A chapter in the story of American Pentecostalism, vol. 2: Since 1941, Gospel Publishing, Springfield.

Brown, H.O.J., 1981, 'The crusade or preventive war', in R.G. Clouse (ed.), War: Four Christian views, pp. 151-188, InterVarsity, Downers Grove, IL.

Burger, I. \& Nel, M., 2008, The fire falls in Africa: A history of the Apostolic Faith Mission of South Africa, Christian Art, Vereeniging.

Burger, I.S.V.D.M., 1987, 'Die geskiedenis van die Apostoliese Geloof Sending van SuidAfrika (1908-1958)', published DD dissertation, Evangelie, Braamfontein.

Cargal, T.B., 1993, 'Beyond the fundamentalist-modernist controversy: Pentecostals and hermeneutics in a postmodern age', Pneuma 15, 163-187. https://doi. org/10.1163/157007493X00158

Clouse, R.G., 1981, 'Introduction', in R.G. Clouse (ed.), War: Four Christian views, pp. 9-26, InterVarsity, Downers Grove, IL.

Dempster, M.W., 1991, “'Crossing borders": Arguments used by early American Pentecostals in support of the global character of pacifism', Journal of the European Pentecostal Theological Association 10(2), 63-80. https://doi. org/10.1179/jep.1991.10.2.003

Dempster, M.W., 2001, 'Pacifism in Pentecostalism: The case of the Assemblies of God', in J. Gros \& J.D. Rempel (eds.), The fragmentation of the church and its unity in peacemaking, pp. 137-165, Eerdmans, Grand Rapids, MI.

Giliomee, H., 2004, Die Afrikaners: 'n Biografie, Tafelberg, Kaapstad.

Hauerwas, S., 1981, A community of character: Toward a constructive Christian social ethic, University of Notre Dame Press, Notre Dame.

Hauerwas, S., 1985, Against the nations: War and survival in a liberal society, Winston, Minneapolis, MN

Hauerwas, S., 1988, Christian existence today: Essays on church, world, and living in between, Wipf and Stock, Eugene.

Hauerwas, S., 2001, 'Should war be eliminated? A thought experiment, (1984)', in J. Berman \& M. Cartwright (eds.), The Hauerwas reader, pp. 392-425, Duke University Press, Durham.

Hauerwas, S., 2001, 'On being a church capable of addressing a world at war: A pacifist response to the United Methodist Bishops' pastoral in defense of creation (1988)', in J. Berman \& M. Cartwright (eds.), The Hauerwas reader, pp. 426-458, Duke in J. Berman \& M. Cartw
University Press, Durham.

Heering, G.J., 1952, Karl Barth over het oorlogsprobleem, Hoofdbestuur 'Kerk en Vrede', Amsterdam.

Hershberger, G.F., 1953, War, peace, and non-resistance, Herald, Scottdale.

Holmes, A.F., 1981, 'The just war', in R.G. Clouse (ed.), War: Four Christian views, pp. 115-150, InterVarsity, Downers Grove, IL.

Hoyt, H.A., 1981, 'Nonresistance', in R.G. Clouse (ed.), War: Four Christian views, pp. 27-78, InterVarsity, Downers Grove, IL.

Johnson, J.T., 1975, Ideology, reason, and the limitation of war: Religious and secular concepts, 1200-1740, Princeton University Press, Princeton, NJ.

King, M.L., 1958, Stride toward freedom, Ballantine, New York.

Kwast, L.H., 1995, Een gepasseerd station: Ethische rechtvaardiging van de oorlog? Interkerkelijk Comité Tweezijdige Ontwapening, Hoogeveen.

Lenz, D.D., 2008, “"Visions on the battlefields": Alexander A. Boddy, early British Pentecostalism, and the First World War, 1914-1918', Journal of Religious History 32(3), 281-302. https://doi.org/10.1111/j.1467-9809.2008.00715.x

Mason, C.H., 2006, 'Year Book of the Church of God in Christ for the Year 1926', in D. Jacobsen (ed.), A reader in Pentecostal theology: Voices from the first generation, pp. 213-221, Indiana University Press, Bloomington, IN.

Nel, M., 2016, 'Pentecostalism and the early church: On living distinctively from the world', Journal of Theology for Southern Africa 153, 141-159.

Nuttail, G., 1958, Christian pacifism in history, Basil Blackwell \& Mott, Berkeley, CA.

Robeck, C.M., 1988, 'National Association of Evangelicals', in S.M. Burgess \& G.B. McGee (eds.), Dictionary of Pentecostal and charismatic movements, pp. 634636 , Zondervan, Grand Rapids, MI. 
Rutgers, A.R., 1933, 'De roeping van het Christendom in onzen tijd tegenover het oorlogsvraagstuk', in H.T. Obbink et al. (eds.), Kerk en oorlog: Vijf voordrachten, pp. 110-143, Erven J. Bijleveld, Utrecht.

Schoonhoven, E.J., 1935, Christelijk pacifism nu!, Van Loghum Slaterus, Arnhem.

Severijn, J., 1933, 'De roeping van het Christendom in onzen tijd tegenover het vraagstuk van den oorlog', in H.T. Obbink et al. (eds.), Kerk en oorlog: Vijf voordrachten, pp. 85-109, Erven J. Bijleveld, Utrecht.

Shuman, J., 1996, 'Pentecost and the end of patriotism: A call for the restoration of pacifism among Pentecostal Christians', Journal of Pentecostal Theology 9, 70-96. https://doi.org/10.1177/096673699600400905

Sölle, D., 1983, Of war and love, transl. Rita \& R. Kimber, Orbis, Maryknoll, NY.
Thyen, H., 1972, 'Zur Problematik einer neutestamentlichen Ekklesiologie', in G. Liedke (ed.), Frieden - Bibel - Kirche, pp. 96-173, Ernst Klett, Stuttgart.

Yoder, J.H., 1971a, The original revolution: Essays on Christian pacifism, Herald, Scottdale. Yoder, J.H., 1971b, Nevertheless: Varieties of religious pacifism, Herald, Scottdale.

Yoder, J.H., 1983, Christian attitudes to war, peace, and revolution: A companion to Bainton, Co-op Bookstore, Eikhart.

Yoder, J.H., 1984, The priestly kingdom: Social ethics as gospel, University of Notre Dame Press, Notre Dame.

Yoder, J.H., 1994, The politics of Jesus, Eerdmans, Grand Rapids, MI.

Zink, Y., 1983, Turn toward life: The Bible and peacemaking, transl. V. Rhodin, Fortress, Philadelphia, PA. 